\title{
Defensive Discourse in Writing about Music ${ }^{1}$
}

\author{
Fred Everett Maus
}

A simple conception of musical experience positions music as an active force, listeners as passive. A defensive resistance to passivity sometimes leads music theory and analysis, and other discourses about music, to divert attention from listening, understood as feminized, while working to establish powerful, active roles for composers, music, and theorists. The essay explores the effects of the active/passive opposition in writing by Eduard Hanslick, Hector Berlioz, John Rahn, Allen Forte, and Edward T. Cone. These analyses summarize fuller treatments by the author in previous essays, here drawn together to show the shared concerns of these writers. The essay concludes by offering ways to complicate or evade simple dualities of active and passive.

Schlichtere Vorstellungen von musikalischer Wahrnehmung verstehen Musik als eine aktive Kraft, Zuhören hingegen als passiv. Ein defensiver Widerstand gegen Passivität führt musiktheoretische, musikanalytische und andere Formen des Diskurses über Musik gelegentlich vom Hören weg, welches als sfeminisiert gilt, um im Gegenzug kraftvolle, aktive Profile für Tätigkeiten in Komposition, Musik und Theorie zu finden. Dieser Aufsatz untersucht die Auswirkungen einer Opposition von saktiv und spassiv s in Texten von Eduard Hanslick, Hector Berlioz, John Rahn, Allen Forte und Edward T. Cohn. Diese Textanalysen greifen ausführlichere Darstellungen des Autors aus früheren Aufsätzen auf, die hier zusammengeführt werden, um eine gemeinsame Tendenz der genannten Autoren herauszuarbeiten. Der Beitrag schließt mit einem Ausblick auf komplexere Formen der Wahrnehmung jenseits von simplen Dualismen wie raktiv und spassiv`.

Schlagworte/Keywords: active-passive opposition; Aktiv-Passiv-Gegensatz; concepts of listening; Hörkonzepte; männlicher Diskurs; masculine discourse; music analysis; music theory; musikalische Analyse; Musiktheorie; Sexualität; sexuality

From 1992 on, I published a number of essays and other texts reflecting on music in relation to gender and sexuality. They have different topics and approaches, but include five essays, published between 1992 and 2013, that develop a single line of thought about music theory and analysis, formalist aesthetics, and musical experience. In this essay I want to summarize and integrate the project shared by those five essays. ${ }^{2}$

From graduate studies onward, my persistent research questions have been about musical experience and about language in relation to musical experience. One of my first publications, "Music as Drama," criticizes the familiar conception of musical analysis as a purely technical discourse. ${ }^{3}$ Analytical descriptions of classical instrumental music, the repertory central to professional music theory at the time of my writing (and only partially displaced in the field since then), often mingle technical and non-technical language; such mixed vocabularies are common in the literature of music theory as well as musical

1 I wrote a brief version of this essay for a session sponsored by the Queer Resource Group of SMT, "Celebrating the Work of Fred Everett Maus," at the 2017 meeting of the Society for Music Theory. I am grateful to Gavin Lee for the creation of that session, and to Ariane Jeßulat for her encouragement to write this expanded version. I have learned a lot in writing each version.

2 Maus 1992, Maus 1993, Maus 2004, Maus 2009, Maus 2013. As discussed below, Maus 1996 also touches on related issues.

3 Maus 1988. 
analysis. These different vocabularies can work together to communicate about musical experience.

In that essay, I begin by producing some detailed musical analysis of my own, trying to stay close to my experience as a listener in a description of the opening of Beethoven's String Quartet in F minor, op. 95. Then I turn to the verbal text of my analysis, taking my own words as an object for analysis and interpretation, asking how my analytical description seems to be representing the music and what generalizations might be drawn from that example.

The outcome is a claim that some music can be understood as a series of imaginary or fictional actions, performed by agents that are typically indeterminate. In forming these ideas, I rely on the concept of action as articulated by analytic philosopher Donald Davidson. ${ }^{4}$ The essay entails a critique of ways of thinking prevalent then and now - music theory and analysis understood as purely technical language, and a philosophy of music that emphasizes emotional expression as the main point of contact between music and human life, without giving attention to other human-like attributions, in particular actions, beliefs, and desires. "Music as Drama" and related essays I wrote around the same time said nothing explicit about gender or sexuality.

My existing orientation to experience and language at the time shaped my interaction with the feminist and queer discourses that entered musicology from the late 1980s on. I came to believe that certain types of language not only fail to capture experience evocatively, but further, they serve as a motivated defense against recognition of some aspects of musical experience.

When I wrote "Music as Drama" (1988), I thought that the scientific, non-experiential orientation of mainstream music theory resulted from the influence of science-based epistemology (in particular, by way of Milton Babbitt's study of analytic philosophy of science), along with the desire of a newly ambitious research discipline to meet respectable academic standards, or some fantasy of those standards. From 1990 on, benefitting from the ideas of Susan McClary and others, I added a psychodynamic account. ${ }^{5}$ Various aspects of musical experience - again, I was thinking mainly of classical instrumental music, but the claim can be generalized - are problematic for some people. These aspects can include intense pleasure of obscure origin, emotionality, irrationality, loss of feelings of self-control, bodily experiences caused by music, and anything that might be understood as tending toward passivity rather than activity. Conceptualizations and verbalizations about music that exclude these problematic aspects can be understood as trying to keep them out of sight, in the same way that, in psychoanalytic theory, the ego's activity of repression hides unwanted psychic content, making it unconscious.

The active/passive opposition, common and typically reductive, compares two entities that are in some relationship, and identifies one as entirely or predominantly doing something to the other, the second entity understood as entirely or predominantly acted upon in that relationship. A simple concept of music listening can identify music as acting upon its listeners, who become passive in that relationship. When the idea of musical passivity comes up in discourse about music, it is often, though not always, stigmatized. One traditional response to musical passivity is to conjure an ideal of active listening, a 
rejoinder that, in this simple form, retains the active/passive contrast and the valorization of the active role.

The active/passive opposition is thoroughly integrated into common reductive oppositions of masculinity and femininity, for instance in concepts of sexual intercourse in which men are active, women passive, and in concepts of other interactions such as verbal conversation between men and women. Scholars of gender and sexuality often identify fear of passivity, and consequent defenses, as a significant component of conventional masculinity. I connect antipathy to musical passivity with antipathy to sexual passivity in particular, fear or disgust toward supposedly feminine sexual passivity, and toward men who are understood to accept for themselves a feminizing sexual passivity. That is, some people stigmatize musical passivity partly because it evokes, perhaps unconsciously, sexual passivity. And I understand these negative feelings to be strongly rooted in projective disavowal of one's own potential for passivity or self-loss. As already mentioned, these dichotomies, active/passive and masculine/feminine, are simplistic. I understand these conceptualizations to be defensive fantasies, and in fantasy, simplification is idiomatic, in particular splitting and schematization.

My understanding of such issues is indebted to literary scholar Leo Bersani. His wellknown 1987 essay "Is the Rectum a Grave?" gives a clear statement of his argument, repeated in various ways in his other writings around that time. ${ }^{6}$ Bersani finds in the excessive intensity of sexual experience a masochistic "shattering" of the self. Strong sensory or affective experiences threaten the fantasy of self-possessed, powerful wholeness - "the masculine ideal of proud subjectivity." ${ }^{7}$ In response to this threat, "self-shattering" can be projected defensively onto the image of a passive sexual partner, the scapegoat in the suppression of the more universal fragility of selfhood. By projection, I understand that some disturbing aspect of oneself is attributed to someone else instead, and thereby magically removed from oneself. This yields fantasies, disturbing but also alluring, of women and gay men degraded by their passivity and self-loss. "It is possible to think of the sexual as, precisely, moving between a hyperbolic sense of self and a loss of all consciousness of self. But sex as self-hyperbole is perhaps a repression of sex as self-abolition." ${ }^{8}$ Identification with phallic images of power disavows the threat of one's own powerlessness. Bersani finds insight in experiences of self-loss, which offer a critique of fragile, and therefore tenaciously defended, aspirations to mastery.

Bersani describes a fear of self-loss, and a consequent defensive projection of passivity onto others, as a response to sexual experience. I suggest we can search for parallels in relation to music, experiences in which the self-possession, wholeness, and agency of the self are threatened, leading to defensive responses. Bersani's dramatic language of "selfshattering" and "self-abolition" may be extreme in relation to some experiences of music, in which self-loss and receptivity can take gentler forms (though Hector Berlioz, for one, was drawn to experiences aptly described as "self-shattering"; see below). Still, as I argue, threats of self-dissolution in musical experience have motivated fantastic defensive postures of activity and control.

The active/passive contrast is typically defensive in its reductive organization of complex experience through a simple binary, and in the affirmation of and identification with

$\begin{array}{ll}6 & \text { Bersani } 2010 . \\ 7 & \text { Ibid., } 29 . \\ 8 & \text { Ibid., 25. }\end{array}$


the active and masculine side of the binary. In this essay I look for the influence of the active/passive opposition, and its defensive use, in verbal texts about music by five authors - John Rahn, Eduard Hanslick, Hector Berlioz, Allen Forte, and Edward T. Cone. In doing so, I gather material from my previously published work. The goal is not primarily to present new research or new ideas, but through a survey of existing studies to draw out common themes. ${ }^{9}$ Near the end of the essay, the section on "Alternatives" and my comments on "Music as Drama" offer some new material.

Apart from Hanslick, the authors I discuss do not explicitly cast their discourse in terms of active and passive roles. Still, I believe these concepts bring out significant patterns in the texts. That is, I believe this familiar opposition shapes the authors' ideas, though not through conscious formulation as such. Cone's text is complex. It includes elements well understood in terms of the active/passive contrast, but I suggest that it might better be summarized in terms of relations of dominance and submission, or top and bottom, in sado-masochistic sexual practices.

The texts I interpret include a skillful survey of options for music theory and analysis (Rahn), a foundational classic of professional music theory (Forte), and a classic of nonconformist "alternative" music theory (Cone). In addition, I discuss a book on musical aesthetics, not itself a work of music theory or analysis, but which has often been understood as stating a conception of music and listening that matches the assumptions of technical theory and analysis (Hanslick). Passages from Berlioz's writings, not musictheoretical in any present-day sense, nonetheless share the framing of musical experience in dramas of activity and passivity and show the opposition worked out in a different idiom.

\section{GeNDERED OpPOSITIONS IN THEORY AND ANALYSIS}

The essay "Masculine Discourse in Music Theory" (1993) identifies different styles of music theory and analysis as enhancing the masculinity or risking the femininity of a practitioner's image and self-image. ${ }^{10} \mathrm{~A}$ theorist who is concerned, more or less unconsciously, with displaying masculinity may make certain choices in verbal expression about music, conforming to general norms of masculine thought and language-use. To support this claim, "Masculine Discourse" turns to an essay by Rahn, which gives an orientation to different styles of then-current theory and analysis by articulating four binary oppositions. ${ }^{11}$ Rahn finds that much recent thought about music can be organized by contrasts between digital and analog (which, as he uses the opposition, can be paraphrased as sciences and humanities); in-time and time-out (that is, whether temporal experience of music is central, or eclipsed by non-temporal generalization); concept-driven and datadriven; and (with links to the second pair) theory-of-experience and theory-of-piece. Rahn's pairs do indeed capture contrasts within music research, not least in the Princeton-oriented divide from the 1970s on between Babbitt's work and that of James K. Randall, Benjamin Boretz, and Elaine Barkan. Rahn could have added that the digital, timeout, concept-driven, and theory-of-piece options were all characteristic of mainstream

9 Not surprisingly, the treatments in the full essays are more detailed and complex than the summaries in this essay.

10 Maus 1993.

11 Rahn 1979. 
theory at the time (1979) as they are, to some extent, to the present, and the other options were associated with work likely to be seen as experimental, marginal, or dissident.

Someone acculturated to feminist theory will also notice that Rahn's pairs all match common stereotypes of binary gender difference. And the same qualities that associate with mainstream professional work also associate with masculinity. Music theory and analysis, at least in the time of Rahn's and my essays (in 1979 and 1993), can be understood as structured by a mainstream and its alternatives, a contrast that reflects and embodies gender difference. To become a mainstream theorist is to speak with a masculine voice. To choose alternative modes of expression is to leave the mainstream and risk or invite or accept an attribution of femininity, most likely through other attributions that are coded as feminine (such as "not rigorous," "unprofessional," "subjective"). This is to some extent independent of the everyday non-professional gender of the particular theorist. $^{12}$

The pair concept-driven/data-driven links readily to the active/passive contrast. Someone who brings powerful concepts to description of music will to some significant extent control the interaction through those concepts; someone who allows data to direct the description will be more passive, allowing the musical details to determine much about the discourse. Rahn also provides alternative language - top-down and bottom-up - for this opposition, and these terms readily evoke the active/passive distinction in sexual roles, in effect offering the theorist the choice of identifying as more active or more passive, depending on whether the discourse and concepts of the theorist dominate the musical evidence or are dominated by it.

The possible association of powerful theoretical concepts with a position of masculine control suggests that some theorists may be drawn to the concept-driven, top-down orientation as a way of performing masculinity. Thus, "Masculine Discourse in Music Theory," as part of a broader distinction between masculine and feminine discourse in music theory, identifies the effects of an active/passive distinction, along with potential for anxiety about the passive role. Rahn himself is notably even-handed about the oppositions he describes. ${ }^{13}$ (See below, in comments on Cone, Cusick, and Hoppe, for more on tops and bottoms.)

\section{ACTIVE LISTENING}

Hanslick's treatise On the Musically Beautiful emphasizes the distinction between active and passive roles, and strongly favors activity. ${ }^{14}$ Hanslick urges listeners to maintain alert, disembodied attention to sounds and their relationships, an approach well-suited to the aspects of music that conventional theory and analysis address. At the same time, the treatise contains a disorganized but vivid counter-discourse of animistic and bodily images. For instance, Hanslick elaborates a comparison between music and arabesque in visual art:

13 Ibid., 271-273.

14 Hanslick 2018. For the most part, in this essay when I quote from writers discussed in my previous essays, the quotations are as in the earlier publications. The exception is Hanslick's treatise, for which I use a new translation of his book. 
How the heavy and delicate lines [in an imagined arabesque that moves] pursue one another, ascend from small curves to magnificent heights, and then sink back again, expand, contract, and surprise the eye ever anew with a rational alternation of repose and tension! [...] Let us imagine this animated arabesque altogether as an active emanation of an artistic mind that unceasingly pours the entire wealth of its imagination into the arteries of this movement. Does this impression not approximate a musical one? ${ }^{15}$

It is easy to find, in this description, an animism that not only grants motion to the arabesque, but populates it with living creatures. "Expansion and contraction" and other details, and especially the musical arabesque flushed with blood, also invite sensuous and erotic associations. Hanslick, or someone wishing to preserve a traditional interpretation of Hanslick, could say that the passage uses metaphor, itself an ambiguous claim (because the relation of metaphorical language to experience would remain to be determined). I find it more accurate to say that such language reports fantasies that can be constitutive parts of listening. Animated and eroticized language like this finds its way into Hanslick's treatise, in tension with his official position.

According to Hanslick, the appropriate kind of pleasure in music comes from "following and anticipating the intentions of the composer," which yields "intellectual gratification." ${ }^{16}$ Such listening, relatively disembodied, aspires to mental appreciation of the composer's active creativity, and, since the listener is thinking like a composer, a kind of identification. This is the conception of the relation between the composer or music and the listener that Suzanne Cusick has shrewdly named "the mind-mind game," and it works as a defensive discourse, doing what it can to evade the potential passivity of listeners. ${ }^{17}$ Hanslick imagines the composer exerting power over a special world:

Following the creative intellect has an elevated and significant effect as it magically reveals to us a new world of elements, coaxes them into all imaginable relationships with each other, and so builds, tears down, produces, and destroys, ruling over the entire wealth of a domain that enables the ear to become the subtlest and most highly developed tool of the senses. ${ }^{18}$

Here the "creative intellect" is conceived as active in relation to a passive realm of musical materials, and the listener's noblest possibility is to identify with this activity. The composer's creative force acts upon musical sound, here understood as passive, subjected to control. As for the other side of the opposition, Hanslick gives special energy to his dismissal of passive listening:

It is the elemental aspect of music, sound and motion, that puts the defenseless feelings of so many music lovers in chains, with which they so gladly rattle [...]. By allowing the elemental in music to affect them in passive receptivity, [passive listeners] end up in vague, supersensuously sensuous agitation determined only by the very general character of the piece of music. ${ }^{19}$

Passive listeners allow sound to act upon them, unlike the more artistic listeners who recognize, follow, and identify with the composer's active control of sound. Hanslick emphasizes that listeners who fall into passive, embodied responses cannot also give au-

16 Hanslick 2018, 89.

17 Cusick 1994, 16.

18 Hanslick 2018, 88-89, quoted in Maus 1993, 287.

19 Hanslick 2018, 81-82, emphasis in original; see Maus 1993, 285. 
ditory attention to specific musical details. I see no reason to believe this assertion, which shows the simplifying force of a fantasy-based binary conceptualization.

From such examples, I argue that Hanslick's famous formalism, urging listeners to give attention to musical sounds as formed by the composer, without distraction, is a defense against the allure of animistic, passive, embodied, and eroticized listening. The argument requires attention to inconsistencies in Hanslick's text and an interpretation that goes beyond Hanslick's overt intentions.

\section{From PAssive Listening to Active Composition}

Berlioz wrote often about music, though not in ways which resemble professional music theory. Unlike Hanslick, he writes enthusiastically about embodied responses to music (and to much else). In Berlioz's descriptions of his own listening, music overwhelms him, physically and mentally. He maintains that music should ravish the listener. "I want music to put me in a fever, to set my nerves on edge. Do you imagine, Monsieur, that I listen to music for pleasure?" ${ }^{20}$ He describes the typical culmination of his most intense musical experiences: "there are spasmodic muscle contractions, trembling of all the limbs, total numbness of the feet and hands, partial paralysis of the nerves of vision and hearing, I don't see, I scarcely hear; dizziness... half-fainting..." ${ }^{21}$ But while Berlioz emphasizes such shattering experiences, which can be of music, of literary works by Shakespeare or Virgil, or of a remarkable woman, they inspire him to want to write music, to move into the active position, to ravish an audience. He sees Harriet Smithson in a Shakespeare play, with this result:

A feeling of intense, overpowering sadness came over me, accompanied by a nervous condition like a sickness, of which only a great writer on physiology could give any adequate idea. I lost the power of sleep and with it all my former animation, all taste for my favorite studies, all ability to work. ${ }^{22}$

To court Smithson, he composes the Symphonie fantastique and arranges for her to hear it:

The brilliant reception, the passionate character of the work, its ardent, exalted melodies, its protestations of love, its sudden outbursts of violence, and the sensation of hearing an orchestra of that size close to, could not fail to make an impression - an impression as profound as it was totally unexpected - on her nervous system and poetic imagination, and in her heart of hearts she thought, "Ah, if he still loved me!"23

Thus, while Berlioz willingly shares stories of being overwhelmed, he defends against self-loss by recovering the active position.

20 Rose 2001, 109, emphasis in original, quoted in Maus 2009, 127.

21 Berlioz 1994, 4 (translation of Berlioz 1862, 6), quoted in Maus 2009, 124 (I have altered the published translation).

22 Berlioz 1969, 95-96 (translation of Berlioz 1870, 66), quoted in Maus 2009, 128.

23 Berlioz 1969, 216 (translation of Berlioz 1870, 186), quoted in Maus 2009, 130. 


\section{ACTIVE WRITING}

Forte's essay "Schenker's Conception of Musical Structure" gives an introduction to Schenkerian analysis, framed explicitly as a contribution to the research discipline of music theory, still in formation at the time of writing. ${ }^{24}$ The article is surely intended to feel like a scientific contribution. My reading, however, focuses on language and rhetoric, and the figure of the author that they create, treating the essay as a literary work.

In Forte's account, Schenker emphasizes the orderly arrangement of musical materials and the relations of "control" and "subordination" among background, middleground, and foreground phenomena. At the same time, the verbal materials of the essay also emphatically show authorial control, with many explicit organizational signposts. Curiously, at several points there are details that create small rhymes between musical structure, as described in the essay, and the essay's own procedures. For instance: "Schenker then shows how this initial prolongation is followed by a restatement [...]. To recapitulate, there are two prolongational classes shown in this background sketch." ${ }^{25}$ The musical "restatement" is immediately succeeded by the essay's own "recapitulation." And curiously, musical and verbal terms seem to have swapped places - the "restatement" is musical, the "recapitulation" is verbal. It is as though the essay is a linguistic composition that conspicuously shares organizational principles with musical composition as understood by Schenker.

Meanwhile, Forte's essay treats listening in a strange way. On one hand, the importance of listening as the basic of musical knowledge receives strong emphasis; on the other hand, the essay's five references to listening are brief and abstract, each one limited to a single sentence. The language of this essay mostly hides listening, instead developing the image of a skillful writer who actively controls the content of the essay, and whose behavior resembles that attributed to the music itself. Here the mind-mind game is energized into a maker-maker game, or controller-controller game, enhancing the active role on both sides and defensively displacing the possibly passive moment of listening.

\section{SUBMISSIVE LISTENING AND IDENTIFICATION}

Cone's book The Composer's Voice (1974) influentially introduces the anthropomorphic concepts of persona and agent. A musical composition has a persona, that is, a humanlike character that is not identical with the composer but which, like the composer, is responsible for everything in the work. The persona "is to be posited as an intelligence embracing and controlling all the elements of musical thought that comprise a work." ${ }^{26}$

A composition may evoke less all-encompassing human-like figures as well; in particular, distinct instrumental parts may be understood as agents, interacting within the total texture. But "in the last analysis all roles are aspects of one controlling persona, which in turn is the projection of one creative consciousness - that of the composer." ${ }^{27}$

26 Cone 1974, 109, quoted in Maus 2004, 23 (emphases added in Maus 2004 have been removed in this and the following quotations). 
Though the entities are different in Forte's and Cone's descriptions - pitches or imaginary living beings, respectively - in both cases the organization of a composition comes from power relations, in which more powerful entities control less powerful ones, a pattern I also noted in Hanslick.

Cone, unlike Forte, complements his account of power and control in music with a description of listening. Cone notes that many people have a stream of musical thought as part of their everyday experience, and places composition and listening in relation to this stream: "To compose is to control this inner voice, to shape it into new forms, to make it speak for us. To listen to music is to yield our inner voice to the composer's domination." ${ }^{28}$ As I understand Cone's views, the ordinary relation to one's ongoing inner music is not clearly active nor passive; the inner music could be described as something we do, but we don't do it intentionally - just as we breathe without needing to breathe intentionally. It could equally be seen as something that happens to us. A composer chooses to become active and controlling in relation to this voice; a listener chooses to submit passively to the composer, allowing the inner music to be dominated from outside. Interestingly, Cone combines this account of listeners' passivity with an account of identification. "To listen to music is to yield our inner voice to the composer's domination. Or better: it is to make the composer's voice our own." ${ }^{29}$ The wording is strange; the phrase "or better" could suggest that the second wording paraphrases the first, improving the expression of the same point. But here, the two phrases - "yield to domination," "make it our own" - seem to refer to two distinct components of a complex phenomenon, submission and identification. To "yield to domination" is to relinquish power and control. To "make the composer's voice our own" is to gain access, through identification, to the composer's power. "Or better" seems to reveal a preference for the more active role.

The combination of submission to, and identification with, an external controlling entity can also structure sexual activity. A similar description appears, as it happens, in a popular experience-based self-help book about sado-masochistic sex: "I struggle and wonder if I can take it all. That struggle seems to make me stronger, and soon I feel intense energy running through me, as if all the force with which the whip is thrown at me is injected into me, becomes my energy to play with." ${ }^{30}$

Music, on Cone's account, invites listeners to take part in something like a sadomasochistic interaction, willingly experiencing powerlessness while also identifying with power. In this account, the listener can no longer be called purely passive; we can borrow the sado-masochistic terms "top" and "bottom" to describe the relationship between persona and listener.

\section{ACTIVE AGENTS}

I want to return briefly to my early essay "Music as Drama." That essay draws on experiences of listening, though in reading it now, I notice that other words are used to state the project of its lengthy analytical description. "I have tried to articulate my understanding of the passage [from Beethoven's String Quartet op. 95] as clearly and flexibly as 
possible." ${ }^{31}$ The word "understanding" tends toward a mind-mind framing, and the sentence emphasizes my own activity as a writer. The description of music is experiencebased, but the diction is that of a "theory of piece," not foregrounding me as a subject of experience. "The new passage registers an awareness of peculiarities of the opening and an effort to clarify, but again there is abruptness throughout, and new peculiarities appear. Response to the earlier problems comes in various ways." ${ }^{\prime 2}$ The music is narrated in terms of awareness and problem-solving - mental cognition and purposeful, wellfounded action. In general, a central contribution of the article, as I indicated before, is to bring concepts of "action" and "agency" to the center of its account, while giving a sideeye to philosophers' traditional emphasis on emotion, thus emphasizing activity over feelings that could be understood as relatively passive responses. "Music as Drama," I must acknowledge, is one more example of the music theorist's preference for activity and devaluing of passivity.

\section{AlTERNATIVES}

This concludes my tour of several texts about music, all shaped by the active/passive distinction. I suggested at the beginning that the active/passive contrast is often reductive. It can be understood as a defensive formation in response to the complexities of lived experience. Thus, one should not assume that these texts are reliable guides to musical experience.

One appropriate way to respond to these readings would be to look for similar patterns in other texts. In another essay by Allen Forte, Marion Guck finds a pattern similar to what I identify in "Schenker's Conception of Musical Structure," and in the work of Jonathan Bernard she identifies an emphasis on concepts of dominance and control. ${ }^{33}$

But, perhaps more importantly, one can wonder how we might move past these representations, in better verbal formulations or perhaps also in altered experiential possibilities. We can try to find descriptions of musical experience that evade active/passive conceptualization. For instance, it might be possible to think about listeners in terms of their trust and vulnerability, rather than passivity or anything like it. I find such ideas very promising. In the rest of this essay, though, I will consider some descriptions that continue to relate to the active/passive contrast while significantly reworking it and moving past it.

In "Love Stories" (1996), an essay consisting mostly of memoir, I write this, recalling a teen-age experience of Ferruccio Busoni's Piano Concerto:

My relation to the piece was also physical: I loved to be in the presence of its sounds. I remember one afternoon when I wanted to listen to the piece. I was alone at home. I closed the curtains and started the recording; I lay on my back on the floor, in the dark, with my feet toward the speakers. It seemed comfortable and appropriate. I was lost in the piece when, abruptly, someone came in the front door and turned on the light - it was my brother-in-law Steve, the one who had once owned a racecar (but by now, one of his friends had stolen the car and totaled it while fleeing the police). Steve didn't say anything; he just looked at me with what I took to be unsurprised disgust and went on to the back of the house. I was upset and embarrassed. I evoked the

31 Maus 1988, 60.

32 Ibid., 63.

33 Guck 1994, Guck 1993. 
familiar idea of Steve as an outsider to our family and told myself: "He will never understand us." But I knew that my listening posture, and my whole relation to the Busoni, would seem odd to my parents as well. I also knew that my embarrassment came from a fear of being, in some sense, understood too well: Steve's presence had given me a glimpse of myself from a perspective of normative masculinity, and I could not tell whether I now found myself ridiculous. ${ }^{34}$

This description displays the potentially passive role of the listener, placing my body in a position to be penetrated by the music. It attributes the defensive masculine role to a disapproving, alien observer, with whose more normative reaction I do not fully identify. Thus, it does not participate in a defensive disparagement of passivity.

But there is more to my relation with the Busoni, in that essay, than my physical listening posture. There is also interpretation - at once technical, emotional, and dramatic:

There was a dominant pedal, and then a loud return of the opening theme. The theme and the harmony were diatonic, but the voice-leading and harmony were awkward and dissonant. I thought this meant that triumphant returns might not be simple or unequivocal. A rising sequential passage, moving eventually to a cadence, was clear in its melody but seemed to lose its harmonic direction briefly. That was easy to understand: strong desire accompanied by confusion.

Then, the breathtaking moment that I always waited for: a sudden passionate melody, new to the piece, operatic in its openness, an emotional outburst with simple tremolo accompaniment. This moment seemed to assert the possibility of finding the right way to convey strong feeling, with no awkwardness and no reserve - except that the piece immediately revised the phrase into its more characteristic style, equivocal and complex. So perhaps, after all, the piece shared my painful doubts about the possibility of such direct, graceful expressiveness. Then, not quite relevantly, the orchestra seemed to glimpse the solo piano part, abruptly abandoning its own train of thought to welcome the new character [...]. I formed interpretations in order to understand the piece, but I knew that my interpretations often mirrored my own concerns. ${ }^{35}$

In this listening, there is concentrated attention on the sounds of the music, and these sounds spontaneously yield interpretations. The interpretations change the music, making it into something that did not exist before my intervention. And the content that I attribute to the music has palpable relations to the personal non-musical concerns of my life; listeners with different lives would not arrive at my version of the music. Somehow, my attentive listening and my individual psyche collaborate to create something that feels like one thing. While my physical posture might suggest a kind of passivity, the total experience is not well described as active or passive. I can say that the music is doing something to me, or that I am doing something to the music, or simply that something is happening to me; this means that active and passive are, at best, part of a complicated story here.

These passages from "Love Stories" show a different descriptive style from that in "Music as Drama," a change in what I was willing to put forth as professional writing about music. In my life, these relationships to music came in the reverse order: I was able to write "Music as Drama" because I had had experiences like the ones described in "Love Stories." "Music as Drama" is the sublimation of those personal experiences. It reshaped what I knew about music into a document that I hoped could get me a job, or a publication, or at least a spot on the program of a conference. As already noted, it did this in part by emphasizing agency, a concept on the active side of the active/passive contrast. I 
don't blame the young, unemployed author of "Music as Drama" for trying to balance personal experience with a professionally viable style, but I am glad that I came to recognize the limitations of that compromise.

Cusick asks, of relations between music and listener, the question "who's on top?," replacing the active/passive binary with words drawn from everyday sexual experience and subject to whatever intricacies exist in that source. ${ }^{36}$ This is an important shift. Active and passive are, in English, somewhat abstract terms, and vernacular vocabulary for talking about sex has many other terms for roles and positions, enriched by their continuity with actual sexual practices - the sado-masochistic terms "top" and "bottom," for example, which I mentioned in relation to Cone, and here the question "who's on top." ${ }^{37}$ Drawing on her sensibility as a lesbian (the basic project of her essay), Cusick memorably complicates the answer to the question, describing listening in a way that moves beyond a stereotype of one-directional power:

The chain of events in my "lesbian aesthetic" response, if it can be said to exist, leads to a preference for musics which invite extremely sensual, heightened, cognitive attention, musics which invite and allow me to participate or not as I choose, musics with which I experience a continuous circulation of power even when I let the music be "on top." ${ }^{38}$

If the role of the listener implies a general identification of the music as "on top," nonetheless the power relations need not be unidirectional or stable.

Another way around a simple active/passive account of music and listener is to give attention to the role of the performer, elided in the music-active/listener-passive scheme and in the mind-mind game. Cusick writes:

It is an active response - the joining of my body to the music in which "who's on top" keeps changing - which is truly my preferred response to music [...]. When I play the fourth variation [of Bach's Canonic Variations on "Vom Himmel hoch"], a great deal of my pleasure derives from the jumbling of who's on top - am I playing "Vom Himmel hoch," or is she playing me? In all performances that give me joy, the answer is unclear - we are both on top, both on our backs, both wholly ourselves and wholly mingled with each other. Power circulates freely across porous boundaries; the categories player and played, lover and beloved, dissolve. ${ }^{39}$

There is a shift, within this description, from the starting point of change in who is on top, through unclarity about roles, to a dissolving of roles. Constant change would imply that roles can still be distinguished. Cusick, then, describes a kind of experience in which the concept "on top" is sometimes relevant, but unstable, and sometimes not relevant at all.

Pauline Oliveros identifies and challenges the idea that listening is passive, in her characteristic playful style:

Browsing in a psychology text, I came across the notion that music is a phallic phenomenon because it penetrates the ear! What a physiological displacement! Did someone lose his body? Come now, Freudians, one can receive music but also actively penetrate it, not to mention all

This is relative to a specific language and local usage within that language, of course. In gay male vernacular Spanish, the terms "activo" and "pasivo" (or often the feminizing "pasiva") are used much as gay English-speaking men use "top" and "bottom."

38 Cusick 2006, 74, emphasis in original.

39 Ibid., 77-78. 
the other finer variations. Maybe we need banana shaped ears. Maybe the psychologist assumed that only men (probably dead men) write music. According to a certain social paradigm, it follows then, that maybe only women should listen to it! or eat it. Of course that paradigm leaves out a large assortment of very fine variations in relationships. How many of you out there think you are in the minority? If everyone came out of the closet the world would change overnight Rattle them bones! Rattle them cages! ${ }^{40}$

Oliveros mentions an explicitly sexualized account of active and passive in music listening, and then begins to exclaim and make jokes. Listening includes reception but also penetration and "all the finer variations." She links this phallic image of music to the prevalence of male composers and the "social paradigm" of normative heterosexuality, which, however, leaves out many "very fine variations in relationships." She suggests that a psychology that recognizes only active music and passive listening is related to a vision of sexuality that recognizes only active men and passive women, notes that there are many more sexual possibilities, and acknowledges that discretion about sexual variety makes the "large assortment of finer variations" of sexual practices harder to recognize. She benefits from her personal knowledge as a lesbian to get past heterosexist stereotypes of musical experience, and she implies that greater openness about sexual diversity would benefit musical life in general.

Oliveros doesn't just comment on the inadequacy of a phallic conception of music. In many of her most characteristic creations, the text scores such as Sonic Meditations (1974) and Deep Listening Pieces (1990), she reconfigures the relations between music and listener: by eliminating specialized roles of performer and audience, inviting all participants to make sound and also to listen continuously, she leaves no place for fixed active and passive roles. ${ }^{41}$ In some cases, structured alternation between sounding and listening is basic to the music. The "Tuning Meditation" asks members of a group to sing long tones, inhaling and exhaling at a natural pace, and in choosing pitches, each person alternates between matching the pitch that someone else is singing and contributing a pitch from their own imagination. ${ }^{42}$ Participants switch between the heightened activity of singing a note and the receptivity of inhaling and listening, and between the receptivity of hearing another person's note in order to match it, and the greater activity of contributing one's own new note. Like Cusick in performing Bach, participants in the "Tuning Meditation" experience a continuous, pleasurable "jumbling of who's on top."

As already mentioned, it can be useful to replace the fantastically simple active/passive contrast with vernacular terms that relate to the complexities of everyday sexual experience. In "Classical Concert Music and Queer Listening," I explore positions that might be miscalled "passive," using sociologist Trevor Hoppe's research on the bottom role in gay male sex and cultural studies scholar Ann Cvetkovich's account of lesbian femme subjectivity. ${ }^{43}$ (Note that the words "top" and "bottom," as they appear in sadomasochistic and also gay male vernaculars, mark different, though not unrelated, contrasts.) These lead me to suggest possible relations to music, which could be summarized in general as "listening as a musical bottom" and "listening as a musical femme." From Hoppe's work I find my way to these questions: 
Do you imagine, sometimes at least, that the feelings and activities in music that you hear are responses to your presence? That you somehow stir the music, provoking it, causing it to have strong feelings? Can you imagine that you take pleasure in the desire and excitement that you can cause in the music? Or that the music uses you to cause its own pleasure and other strong feelings, perhaps without caring much about your experience - and that this whole configuration, nonetheless, is the source of your own pleasure? ${ }^{44}$

And from Cvetkovich I drew these possibilities:

that music wants to give pleasure to its listeners; that the listener desires musical pleasure but fears its cost in vulnerability or loss of control; that the music can reassure the listener about the listener's musical pleasures; that the listener's desirous receptivity may be continuous with a broader desire for knowledge by experience, by taking in parts of the world, and may yield poetic knowledge. ${ }^{45}$

I find it wonderfully provocative to think about these possibilities - the ones I can imagine and the ones I can't quite. Sexual realities can counter reductive sexual fantasies and lead to unfamiliar, provocative questions. Allegiance to the active music/passive listener contrast can explain some of our habits of professional thought about music, specifically a recurring masculine anxiety about passivity and eagerness to construct active roles, but getting past that simple contrast opens fascinating possibilities for imagining musical experience.

\section{References}

Berlioz, Hector. 1862. À travers chants. Paris: Michel Lévy Frères.

Berlioz, Hector. 1870. Mémoires. Paris: Michel Lévy Frères.

Berlioz, Hector. 1969. The Memoirs of Hector Berlioz. Translated and edited by David Cairns. New York, Knopf.

Berlioz, Hector. 1994. The Art of Music and Other Essays. Translated and edited by Elizabeth Csicsery-Rónay. Bloomington: Indiana University Press.

Bersani, Leo. 2010. "Is the Rectum a Grave?" [1987]. In Is the Rectum a Grave? and Other Essays. Chicago: University of Chicago Press, 3-30.

Cone, Edward T. 1974. The Composer's Voice. Berkeley: University of California Press.

Cusick, Suzanne G. 1994. "Feminist Theory, Music Theory, and the Mind/Body Problem." Perspectives of New Music 32/1: 8-27.

Cusick, Suzanne G. 2006. "On a Lesbian Relationship with Music: A Serious Effort Not to Think Straight." In Queering the Pitch: The New Gay and Lesbian Musicology, edited by Philip Brett, Elizabeth Wood, and Gary C. Thomas. Second edition. New York: Routledge, 67-83.

Cvetkovitch, Ann. 1995. "Recasting Receptivity: Femme Sexualities." In Lesbian Erotics, edited by Karla Jay. New York: New York University Press, 125-146.

45 Ibid., 9. 
Davidson, Donald. 2001. Essays on Actions and Events. New York: Oxford University Press.

Easton, Dossie / Catherine A. Liszt. 1995. The Bottoming Book, or, How to Get Terrible Things Done to You by Wonderful People. San Francisco: Greenery Press.

Forte, Allen. 1959. "Schenker's Conception of Musical Structure." Journal of Music Theory 3/1: 1-30.

Guck, Marion A. 1993. "The 'Endless Round.' (Jonathan Bernard on Edgard Varese)." Perspectives of New Music 31/1: 306-314.

Guck, Marion A. 1994. "Analytical Fictions." Music Theory Spectrum 16/2: 217-230.

Hanslick, Eduard. 2018. On the Musically Beautiful: A New Translation. Translated by Lee Rothfarb and Christopher Landerer. New York: Oxford University Press.

Hoppe, Trevor. 2011. "Circuits of Power, Circuits of Pleasure: Sexual Scripting in Gay Men's Bottom Narratives." Sexualities 11/14: 193-217.

Maus, Fred Everett. 1988. "Music as Drama." Music Theory Spectrum 10/1: 56-73.

Maus, Fred Everett. 1992. "Hanslick's Animism." Journal of Musicology 10/3: 273-292.

Maus, Fred Everett. 1993. "Masculine Discourse in Music Theory." Perspectives of New Music 31/2: 264-293.

Maus, Fred Everett. 1996. "Love Stories." Repercussions 4/2: 86-96.

Maus, Fred Everett. 2004. "The Disciplined Subject of Musical Analysis." In Beyond Structural Listening: Postmodern Modes of Hearing, edited by Andrew Dell'Antonio. Berkeley: University of California Press, 13-43.

Maus, Fred Everett. 2009. "Virile Music by Hector Berlioz." In Masculinity and Western Musical Practice, edited by lan Biddle and Kirsten Gibson. Farnham: Ashgate, 113-133.

Maus, Fred Everett. 2013. "Classical Concert Music and Queer Listening." Transposition. Musique et sciences sociales 3 (Special Issue: Music and Queer Theory). https://journals.openedition.org/transposition/148 (15 Apr 2020)

McClary, Susan. 2002. Feminine Endings: Music, Gender, \& Sexuality [1991]. Second edition. Minneapolis: University of Minnesota Press.

Oliveros, Pauline. 1974. Sonic Meditations. Baltimore: Smith Publications.

Oliveros, Pauline. 1984. Software for People: Collected Writings 1963-1980. Baltimore: Smith Publications.

Oliveros, Pauline. 1990. Deep Listening Pieces. Kingston: Deep Listening Publications.

Oliveros, Pauline. 2013. Anthology of Text Scores. Kingston: Deep Listening Publications.

Rahn, John. 1979. "Aspects of Musical Explanation." Perspectives of New Music 17/2: 204-224.

Rose, Michael, ed. 2001. Berlioz Remembered. London: Faber. 
Maus, Fred Everett (2020): Defensive Discourse in Writing about Music. ZGMTH 17/1, 65-80.

https://doi.org/10.31751/1035

(C) 2020 Fred Everett Maus (fredmva@gmail.com)

University of Virginia

Dieser Text erscheint im Open Access und ist lizenziert unter einer

Creative Commons Namensnennung 4.0 International Lizenz.

This is an open access article licensed under a

(c) (i)

Creative Commons Attribution 4.0 International License.

eingereicht / submitted: 30/09/2019

angenommen / accepted: 02/12/2019

veröffentlicht / first published: 15/06/2020

zuletzt geändert / last updated: 15/06/2020 